\title{
Study of postures in sugarcane cutters in the Pontal of Paranapanema-SP, Brazil
}

\author{
Iracimara de Anchieta Messias ${ }^{\mathrm{a}}$, Emico Okuno $^{\mathrm{b}}$ \\ ${ }^{a}$ Departamento de Planejamento, Urbanismo e Ambiente, Faculdade de Ciências e Tecnologia, UNESP - Univ \\ Estadual Paulista Rua Roberto Simonsen 305, Presidente Prudente/ São Paulo - Brasil. CEP:19060-900 - \\ iracimara@fct.unesp.br \\ ${ }^{\mathrm{b}}$ Departamento de Física Nuclear, Instituto de Física, USP - Universidade de São Paulo, emico@dfn.if.usp.br
}

\begin{abstract}
The expansion of sugarcane monoculture in Brazil in the last decades has pointed out to the necessity of considering the question of sugarcane cutters occupational health. In this work we present a cross-sectional study aiming to examine the occupational posture of a group of sugarcane cutters, which work in a cane field located in the region of Pontal do Paranapanema-SP, Brazil. The study was made using the Ergonomic Analysis of Work - EAW methodology and the postural analysis method by Win-OWAS. Through the obtained records of postures, it was observed that during a workday the sugarcane cutters remain standing erect on two legs or in one leg $66 \%$ of the time and that their trunk remain tilted and in rotation, according to $63 \%$ of the positions categorized. It was also observed that the sugarcane cutter trunk performs repetitive and boundless movements during his routine of work, which can expose this individual to additional wear of their musculoskeletal functions. The activities in which the individual engages have favorable or adverse influence on his posture. The repetitive movements involved in specialized occupations are equivalent to repeated exercises, thus may be responsible for the excessive development of certain muscle groups. The study suggests that the postures adopted by sugarcane cutters can overload their musculoskeletal system and predispose the cutters to work-related musculoskeletal diseases.
\end{abstract}

Keywords: occupational health, sugarcane cutter, postures, win-owas, musculoskeletal disease

\section{Introduction}

The expansion sugarcane monoculture throughout Brazil in the last decades has stressed the needs of considering issues related to occupational health of sugarcane cutters.

The work of sugarcane cutting can lead to physical and psychic diseases to the worker. This is mainly because the worker remuneration is based on daily production, consequently the individual often does not respect his physical limits or his age and hence the wear and tear due to occupation, which can literally take the worker to die of overwork [1].

The work of sugarcane cutting can causes a severe physical stress, reaching exhaustion, because to cut 12 tons of cane per day the worker has to walk 8,800 meters, hold 133,333 strokes trimmer and 36,630 push-ups and thoracic sprains, losing an average of 8 liters of water per day $[1,2]$.

The State of Sao Paulo accounts for $60 \%$ of national production, corresponding to approximately 4.5 million hectares of land planted with sugarcane, which means a little more than a half of the area occupied with the cultivation of monoculture in the country [3]. The western region of the State of São Paulo, known as the Pontal do Paranapanema, is changing the cattle monoculture for sugarcane in most of its land area. This justifies the development of studies aiming to understand the impact of such a change to the workers' occupational health and also to the environment.

In this note we present a cross-sectional study to assess posture in a group of occupational sugarcane cutters working in a mill in the region of Pontal do Paranapanema, São Paulo, Brazil. 


\section{Methodological}

\subsection{Study design and population}

This is a cross-sectional exploratory study, conducted in a group of sugarcane cutters.

\subsection{Study site}

The analyzed data were collected during the worksite sugarcane cutting working in a mill located in the western region of the State of São Paulo, Brazil. The court was being held in bisada cane, or reed planted and harvested a crop in the other.

\subsection{Instruments}

\subsubsection{Ergonomic Analysis of Work - EAW}

It was used some instruments to observe the principles of work by EAW - Ergonomic Analysis of Work, as described by Guerin [4].

The essential feature of EWA is to examine and reflect the reality of work, whose objective is to understand its determinants in order to answer questions and propose solutions.

Workers' images were collected with the equipment Sony DSC-S600, and filming record were obtained with a Samsung brand model SCA 30.

\subsubsection{Interview}

Unstructured interview was conducted with some cutters during his workday. All the dialogue was accompanied by the tax break does not occur in our journey to its completion.

\subsubsection{Win-Owas Method}

For the postural analysis images were collected on video tape that served to postural assessments as recommended by Win-OWAS method [5]: analyzing postures classified in a time interval of 30s with 100 being the minimum number of observations.

This system is based on sampling of activity in constant or variable intervals, checking the frequency and time spent in each posture. Samples were observed in the positions of the back, arms, legs, use of force and the phase of activity. The postures were categorized by the method win-OWAS that automates and facilitates the analysis process. Once filled the tables of the program, a chart with the classification of the risks of the task is provided.

\section{Results}

It is observed that the work of the sugarcane cutter requires specific physical skills and preparation of his fitness.

Using the win-OWAS method, 245 positions of six sugarcane cutters were classified during their work. For the categorization of positions, the task was divided into two phases, which are the cutting and transportation of cut cane.

In the two phases, $67(27 \%)$ of the postures were classified as category 1 , which does not require immediate changes in the work post. The category 2 had 82 positions (33\%), which requires ergonomic changes in the near future. 41 positions $(17 \%)$ were categorized in category 3 , which requires changes as soon as possible and 55 positions $(22 \%)$ in category 4 , indicating that changes must be made in the post immediately.

The higher frequency of postures in categories 1 and 2 can be explained by the weight carried by the workers, being always less than $10 \mathrm{~kg}$. This factor, according to the program, makes the activity less harmful to workers' health. However there are in this category postures that can cause musculoskeletal discomfort because of constant rotational movements of the trunk [6]. In addition, the program does not analyze separately the lumbar region, which, according to the images, remains flexed most of the time.

Through the records of posture, we observed the same frequency during the workday cutter. It is possible to quantify that they were standing on one leg or two in $66 \%$ of categorized postures, and its trunk is inclined and rotation, according to $63 \%$ of categorized postures.

For Dul [7] the reaches with arms, forward, backward and sideways, should be limited in order to prevent tipping or rotation of the body. It was observed with the records that the sugarcane cutter performs repetitive and boundless movements with his arms during the daily routine of work, which may expose the individual to additional wear of their musculoskeletal functions. 
For Kendall [8] concentrating on a type of activity provides an increasing in the potential for muscle imbalances. The activities in which the individual engages will influence favorable or adverse postures. Thus, the nature of the activity and time spent on it can be reinforced or counteracted its effects on the individual's usual stance. The repetitive movements involved in specialized occupations are equivalent to repeated exercises, and thus may be responsible for the excessive development of certain muscle groups. If the effect of bad posture is reinforced by a repetitive activity, the muscle imbalance is greatly increased.

The movements and postures adopted during the period of work in association with physical and cognitive overload and inadequacies of the job can overload the musculoskeletal system and predispose the sugarcane cutters to Repetitive Strain Injury or work-related musculoskeletal disease.

\section{Conclusions}

According to the data presented, the sugarcane cutters are exposed to many different types of risks in the development of their work.

The work gain based on the daily production may lead these individuals to exceed their physical limits. Associated with this, the issue of fear from constant inspections leads to mental distress, a factor that favors the individual's illness.
The outdoor work, coupled with the need for the use of PPE are in view of the worker, an even greater risk factor for the occurrence of accidents. The presence of smoke and soot can lead to many different types of allergies and respiratory diseases.

The biomechanical loads and postures can lead to the development of diseases of the musculoskeletal system, which can be disabling from the functional point of view.

\section{References}

[1] F. Alves. Porque Morrem os cortadores de cana? Revista Saúde e Sociedade, Vol. 15, n. 3, p. 90-98, 2006.

[2] J.R.P. Novaes. Campeões de Produtividade: dor e febre nos canaviais paulistas. Estudos Avançados, 21 (59), 2007. OKUNO, E.; FRATIN, L. Biomecânica - Desvendando a Física do Corpo Humano. São Paulo: Ed. Manole, 2003.

[3] F.L.R. Rocha; M.H.P. Marziale; M.L.C.C. Robazzi. A Pobreza Como Fator Predisponente ao Adoecimento de Trabalhadores do Corte da Cana-de-Açúcar. Revista Latinoamericana de Enfermagem, Setembro- Outubro (15), 2007.

[4] F. Guerin et al. Compreender o trabalho para transformá-lo: a prática da ergonomia. São Paulo. Ed. Edgard Blucher, 2001.

[5] Win-Owas. Manual software for OWAS analysis. Tampere University of Technology, Occupational Safety. Engineering.14 p. Disponível em: $<$ http://turva.me.tut.fi/owas $>$. Acesso em: 21 de fevereiro de

[6] I. Iida, I. Ergonomia: projeto e produção. São Paulo, Edgard Blucher, 1990. p. 465.

[7] J. Dul, B. Weerdmeester. Ergonomia Prática. Tradução: Itiro Iida. São Paulo:Edgard Blucher, 2004.

[8] P.F. Kendal;, E.K. McCreary; P.G. Provance Músculos Provas e Funções. São Paulo: Manole, 1995. 